Olgu sunumu-Case report

\title{
Supratentoryal ve infratentoryal yerleşimli multiple kavernom olgusu
}

\section{A case of multiple cavernoma located supratentorial and infratentorial}

\author{
Erdal Kalkan, Fatih Keskin*, Yaşar Karataş, Bülent Kaya, Ahmed Önder Güney
}

Nöroşirürji Anabilim Dalı (Doç. Dr. E. Kalkan, Yard. Doç. Dr. F. Keskin, Dr. Y. Karataş, Prof. Dr. A. Ö. Güney), Konya Necmettin Erbakan Üniversitesi Meram Tıp Fakültesi, TR-42080 Konya, Nöroşirürji kliniği (Dr. B. Kaya), İnegöl Devlet Hastanesi, TR-16400 Bursa

\section{Özet}

Serebral kavernöz hemanjiomlar vasküler yapıların nadir görülen malformasyonlarındandır. Sporadik formda lezyonlar genellikle tek iken, lezyonların multipl olması daha çok familyal tipte rastlanılan bir durumdur. Semptomatik hastalar başağrısı, epileptik nöbet, fokal nörolojik defisit, hemoraji veya bunların kombinasyonu ile hastaneye başvururlar. Bizim olgumuz multiple supratentoryal lezyonların yanı sıra infratentoryal tutulumun da birlikte görülmesi ve multiple kavernom olmasına rağmen herediter geçişli olmaması nedeniyle literatürdeki sunumlardan farklılık göstermektedir.

Anahtar sözcükler: Epileptik nöbet, herediter, infratentorial, kavernöz hemanjiom

\begin{abstract}
Cerebral cavernous hemangiomas are rarely seen malformations of vascular stuctures. While sporadic forms usually single lesions, multiple lesions are more common familial type of situation. Symptomatic patients with headache, epileptic seizure, focal neurological deficits, hemorrhage, or combinations of these apply to the hospital. Our case differs from the cases presented in the literature, because it has infratentorial involvement beside multiple supratentorial lesions and our case with multiple cavernoma is not hereditary.
\end{abstract}

Keywords: Epileptic seizure, hereditary, infratentorial, cavernous hemangioma

Geliş tarihi/Received: 15 Haziran 2012; Kabul tarihi/Accepted: 14 Kasım 2012

\section{*İletişim adresi:}

Dr. Fatih Keskin, Nöroşirurji Anabilim Dalı, Konya Necmettin Erbakan Üniversitesi Meram Tıp Fakültesi, TR-42080 Konya. E-posta: drfatihk@yahoo.com

\section{Giriş}

Serebral kavernöz hemanjiomlar vasküler yapıların nadir görülen malformasyonlarındandır. Ayrıca bu patolojiler literatürde kavernöz anjiom ve kavernom olarak da adlandırılır. Kavernöz hemanjiomlar büyük sinüzoidal vasküler boşlukların birleşmesiyle oluşur. İçerisinde musküler ve nöral dokuya ait yapılar izlenmez [1]. Geniş manyetik rezonans görüntüleme (MRG) ve otopsi çalışmalarına dayanılarak yapılan araştırmalarda kavernöz malformasyonlar genel populasyonda \%0,4-0,5 oranında görülürken serebral vasküler malformasyonlar içerisinde \%10-20 oranında görülür [2-4]. Özellikle MRG'nin rutin kullanıma girmesi ile olguların sayısında artış olmuştur [5]. Kavernomlar T1 ve T2 ağırlıklı MRG görüntülemesinde karakteristik olarak merkezde methemoglobine bağlı yüksek sinyalli bir alan ve çevresinde kalsifikasyon ve fibrozise bağlı düşük sinyalli alanlar gösterirler. T2 ağırlıklı kesitlerde hiperintens popcorn benzeri bir görüntüye rastlanabilir [6]. 


\section{Olgu sunumu}

Altmış sekiz yaşında bayan hasta 1 yıldır başağrısı ve zaman zaman vücudunda istemsiz kasılmalar nedeniyle servimize başvurdu. Özgeçmiş ve soygeçmişinde özellik yoktu. Yapılan fizik muayenesinde patoloji saptanmadi. Nörolojik muayenesinde motor ve duyu defisiti yoktu. Rutin laboratuar tetkikleri normaldi. Kranial MR görüntülemesinde her iki serebral hemisfer ve sol serebellar hemisferde yaklaşı $2,5 \times 2 \mathrm{~cm}$ ebadında olmak üzere T1A ve T2A'da heterojen hipointens ve hiperintens alanlar içeren periferinde hipointens hemosiderin artıklarını akla getiren kavernomla uyumlu lezyonlar izlenmiştir. (Resim 12). Komşu parankimde ödem bulgusu saptanmadı. Hastanın çekilen serebral anjiografisinde patoloji izlenmedi. (Resim 3).

Antiepileptik tedavi ile nöbetleri kontrol altına alınan hastanın son yapılan nörolojik muayenesi normal olarak değerlendirildi ve poliklinik kontrolü önerilerek taburcu edildi.

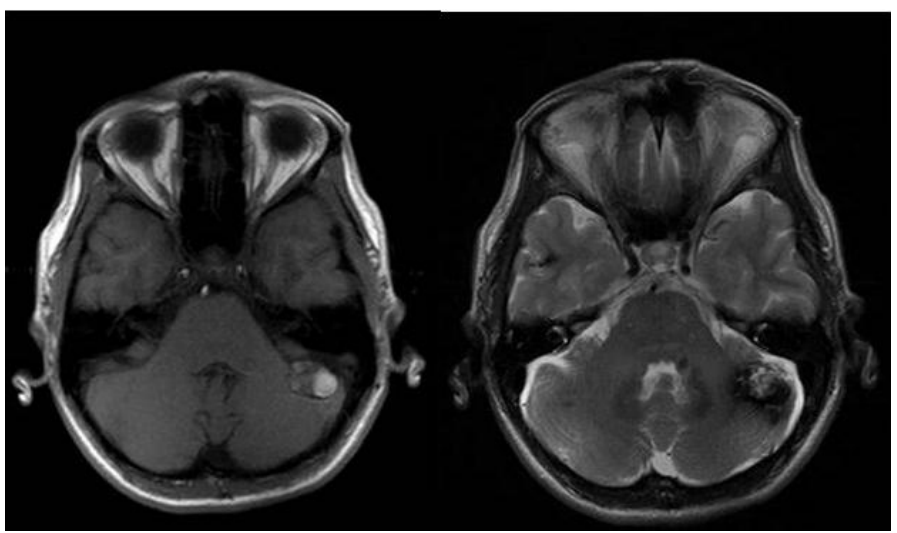

Resim 1. Aksiyel T1A ve T2A MRG'sinde sol serebellar hemisferde yaklaşık $2,5 \times 2 \mathrm{~cm}$ ebadında heterojen hipo-hiperintens lezyon izlenmekte.

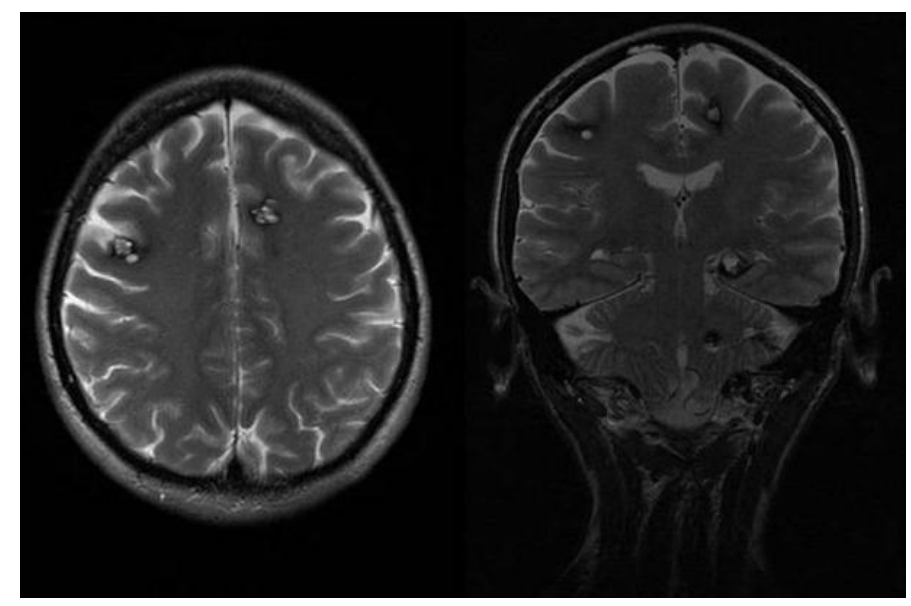

Resim 2. Aksiyel ve koronal T2A MRG'sinde her iki serebral ve sol sereballar hemisferde multipl heterojen lezyonlar izlenmekte.

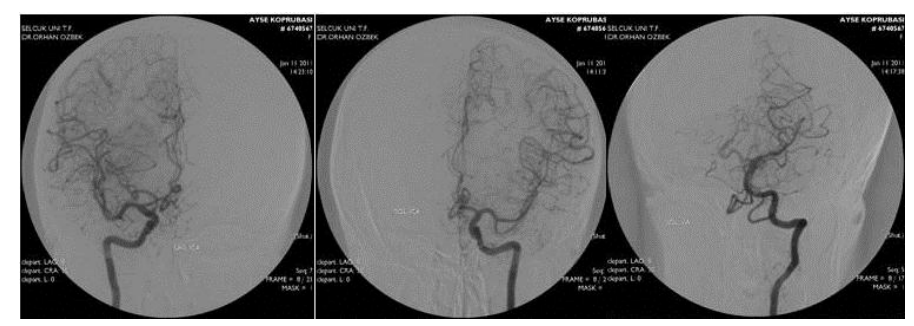

Resim 3. Serebral Anjiografide vasküler yapıların normal olduğu izlenmekte. 


\section{Tartışma}

Kavernöz hemanjiomlar; arteriyovenöz malformasyon, telenjiektazi, venöz anjiomlar ile birlikte vasküler malformasyonlar içerisinde yer alan patolojilerdir. Sporadik ve familyal olmak üzere iki formu tanımlanmıştır. Sporadik formda lezyonlar genellikle tek iken, lezyonların multipl olması daha çok familyal tipte rastlanılan bir durumdur. Robinson ve ark. [7] supratentoryal yerleşimin infratentoryal yerleşimden daha fazla olduğunu bildirmişlerdir.

Russell ve Rubinstein'in yaptığ 1 sinıflamaya göre intraserebral yerleşimli vasküler malformasyonlar; arteriovenöz malformasyonlar, kapiller telenjiektazi, kavernom ve venöz malformasyonlar olarak 4 gruba ayrılır. Bu sınıflama içinden kavernomlar nadir olarak gözlenir ve daha çok intraparenkimal olarak serebral hemisferler, beyin sap1 ve orta beyin bölgelerinde yerleşir. Subaraknoid, subdural, epidural ve intraventriküler yerleşimleri de çok nadir olarak gözlenir [8, 9]. Santral sinir sitemi kavernöz malformasyonları genellikle tek lezyon olarak görülürken, hastaların \%9-18,7 oranında multipl lezyon görülür [10-12]. Multipl lezyonlar çoğunlukla herediterdir ve otozomal dominant geçişlidir. Familyal formla ilişkili genler 3. kromozomun uzun kolu ve 7. kromozomun uzun ve kisa kolunda lokalize CCM1(Cerebral cavernous malformation 1), CCM 2, CCM3 genleridir [13, 14].

Bizim olgumuzda da supratentoryal ve infratentoryal yerleşimli multipl sayıda kavernom mevcuttu. Ancak aile üyelerinden herhangi birinde daha önceden saptanmış bir kavernöz malformasyon yoktu. İntrakranial kavernöz malformasyonlar genellikle asemptomatiktir. Klinik bulgular hastanın yaşı, lezyonun lokalizasyonu, boyutu, sayısı, hemoraji gibi komplikasyonların olmasına göre değişir. Semptomatik hastalar başağrısı, nöbet, fokal nörolojik defisit, hemoraji veya bunların kombinasyonu ile hastaneye başvururlar [15, 16]. Bizim hastamızda da uzun süreli başağrısı şikayeti ve nöbet hikayesi mevcuttu. Frontal ve temporal loblar da bulunan lezyonlarm \%36-39'unda belirgin semptom nöbettir [17]. Komşu parankimin hemosiderin ile irritasyonu potansiyel epileptojenik etki oluşturmaktadır [18]. Fokal nörolojik defisitler daha çok beyin sapı lezyonlarında görülür. Kitle etkisi \%20-32, akut hemoraji bulguları \%19-25, başağrıs1 \%6-8 oranında görülür. Kavernöz malformasyona bağlı hemorajiler genellikle intraparankimal olarak görülür. Nadiren de subaraknoid veya intraventriküler olabilir. Kanamalar da mortalite düşük olmasına rağmen ölümcül kanamalar beyin sapı kavernomlarında yüksek oranda görülür $[19,20]$. Multipl kavernomlarda her lezyon için yıllık kanama riski $\% 0,7$ ile 1,1 arasindadır [21, 22].

Kavernöz hemanjiomların tanısında MRG son zamanlarda kullanılan en güvenilir tanı yöntemidir. Sensivitesi BT incelemeye göre daha yüksektir. Lezyonlar iyi sınırlı, T1A ve T2A imajlarda heterojen sinyal intensitesinde olup genellikle artmış sinyal özellikleri gösterirler. Santral kesimi methemoglobin nedeniyle parlak görünümdedir. Periferik kısmı hemosiderin depositleriyle ilişkili olarak azalmış sinyal intensitesi gösterir [7, 23]. Bizim olgumuzda da MRG'de benzer görünüm mevcuttu.

Sonuç olarak kavernöz hemanjiomlar nadir görülen vasküler malformasyonlardır. Tentoryumun her iki tarafını tutabilmesine rağmen infratentoryal tutulum daha da nadir izlenir. Bizim olgumuz multiple supratentoryal lezyonların yanı sira infratentoryal tutulumun da birlikte görülmesi ve multiple kavernom olmasına rağmen herediter geçişli olmaması nedeniyle literatürdeki sunumlardan farklılık göstermektedir.

\section{Kaynaklar}

1. Smit LM, Halbertsma FJ. Cerebral cavernous hemangiomas in childhood. Clinical presentation and therapeutic considerations. Childs Nerv Syst 1997; 13: 522-5.

2. Mao Y, Zhao Y, Zhou LF, Huang CX, Shou XF, Gong JL, Lawton MT, Yang GY. A novel gene mutation (1292 deletion) in a Chinese family with cerebral cavernous malformations. Neurosurgery 2005; 56: 1149-53.

3. Moriarity JL, Clatterbuck RE, Rigamonti D. The natural history of cavernous 
malformations. Neurosurg Clin N Am 1999; 10: 411-7.

4. Zabramski JM, Henn JS, Coons S. Pathology of cerebral vascular malformations. Neurosurg Clin N Am 1999; 10: 395-410.

5. İplikçioğlu AC, Benli K, Bertan V, Ruacan S. Cystic cavernous hemangioma of the cerebellopontine angle: case report. Neurosurgery 1986; 19: 641-2.

6. de Oliveira JG, Rassi-Neto A, Ferraz FA, Braga FM. Neurosurgical management of cerebellar cavernous malformations. Neurosurg Focus 2006; 15; 21: e-11.

7. Robinson JR, Awad IA, Little JR. Natural history of the cavernous angioma. J Neurosurg 1991; 75: 709-14.

8. Russel DS, Rubinstein LJ. Pathology of tumors of the nervous system: Tumor and hamartoma of the blood vessels, üçüncü bask1, London: Edward Arnold, 1971; 85-108.

9. Sakai N, Yamada H, Tanigawara T, Asano Y, Andoh T, Tanabe Y, Takada M. Surgical treatment of cavernous angioma involving the brainstem and review of the literature. Acta Neurochir 1991; 113: 138-43.

10. Porter PJ, Willinsky RA, Harper W, Wallace MC. Cerebral cavernous malformations: Natural history and prognosis after clinical deterioration with or without hemorrhage. J Neurosurg 1997; 87: 190-7.

11. Otten P, Pizzolato GP, Rilliet B, Berney J. 131 cases of cavernous angioma (cavernomas) of the CNS, discovered by retrospective analysis of 24,535 autopsies. Neurochirurgie 1989; 35: 82-3,128-31.

12. Del Curling O Jr, Kelly DL Jr, Elster AD, Craven TE. An analysis of the natural history of cavernous angiomas. J Neurosurg 1991; 75: 702-8.

13. Craig HD, Günel M, Cepeda O, Johnson EW, Ptacek L, Steinberg GK, Ogilvy CS, Berg MJ, Crawford SC, Scott RM, Steichen-Gersdorf E, Sabroe R, Kennedy CT, Mettler G, Beis MJ, Fryer A, Awad IA, Lifton RP. Multilocus linkage identifies two new loci for a mendelian form of stroke, cerebral cavernous malformation, at 7p15-13 and 3q25.2-27. Hum Mol Genet 1998; 7: 1851-8.

14. Dubovsky J, Zabramski JM, Kurth J, Spetzler RF, Rich SS, Orr HT, Weber JL. A gene responsible for cavernous malformations of the brain maps to chromosome 7q. Hum Mol Genet 1995; 4: 453-8.

15. Rigamonti D, Johnson PC, Spetzler RF, Hadley MN, Drayer BP. Cavernous malformations and capillary telangiectasia: A spectrum within a single pathological entity. Neurosurgery 1991; 28: 60-4.

16. Hausler R, Levine RA. Auditory dysfunction in stroke. Acta Otolaryngol 2000; 120: 689-703.

17. Simard JM, Garcia-Bengochea F, Ballinger WE Jr, Mickle JP, Quisling RG. Cavernous angioma: a review of 126 collected and 12 new clinical cases. Neurosurgery 1986; 18: 162-72.

18. Johnson PC, Wascher TM, Golfinos J, Spetzler RF. Definition and pathological features. In: Awad IA, Barrow DL, eds. Cavernous Malformations: American Association of Neurological Surgeons, Publications Committee; 1993: 1-11.

19. Brown RD Jr, Wiebers DO, Torner JC, O'Fallon WM. Incidence and prevalence of intracranial vascular malformations in Olmsted County, Minnesota, 1965 to 1992. Neurology 1996; 46: 949-52.

20. Fritschi JA, Reulen HJ, Spetzler RF, Zabramski JM. Cavernous malformations of the brain stem. A review of 139 cases. Acta Neurochir (Wien) 1994; 130: 35-46.

21. Labauge P, Brunereau L, Laberge S, Houtteville JP. Prospective follow-up of 33 asymptomatic patients with familial cerebral cavernous malformations. Neurology 2001; 57: 1825-8.

22. Zabramski JM, Wascher TM, Spetzler RF, Johnson B, Golfinos J, Drayer BP, Brown B, Rigamonti D, Brown G. The natural history of familial cavernous malformations: results of an ongoing study. J Neurosurg 1994; 80: 422-32.

23. Brunereau L, Labauge P, Tournier-Lasserve E, Laberge S, Levy C, Houtteville JP. Radiology 2000; 214: 209-16. 